\title{
Src promotes estrogen-dependent estrogen receptor $\alpha$ proteolysis in human breast cancer
}

Isabel Chu, ${ }^{1,2}$ Angel Arnaout, ${ }^{2,3}$ Sophie Loiseau, ${ }^{1}$ Jun Sun, ${ }^{1}$ Arun Seth, ${ }^{4}$ Chris McMahon, ${ }^{4}$ Kathy Chun, ${ }^{4}$ Bryan Hennessy, ${ }^{5}$ Gordon B. Mills, ${ }^{5}$ Zafar Nawaz, ${ }^{1}$ and Joyce M. Slingerland ${ }^{1}$

${ }^{1}$ Braman Family Breast Cancer Institute and Sylvester Comprehensive Cancer Center, University of Miami Miller School of Medicine, Miami, Florida, USA.

${ }^{2}$ Department of Medical Biophysics, ${ }^{3}$ Department of Surgery, and ${ }^{4}$ Department of Pathobiology and Laboratory Medicine, University of Toronto, Toronto, Ontario, Canada. ${ }^{5}$ Department of Systems Biology, University of Texas MD Anderson Cancer Center, Houston, Texas, USA.

\begin{abstract}
Estrogen drives both transcriptional activation and proteolysis of estrogen receptor $\alpha$ (ER $\alpha$; encoded by ESR1). Here we observed variable and overlapping ESR1 mRNA levels in 200 ER $\alpha$-negative and 50 ER $\alpha$ positive primary breast cancers examined, which suggests important posttranscriptional ER $\alpha$ regulation. Our results indicate that Src cooperates with estrogen to activate $E R \alpha$ proteolysis. Inducible Src stimulated ligand-activated ER $\alpha$ transcriptional activity and reduced ER $\alpha t_{1 / 2}$. Src and ER $\alpha$ levels were inversely correlated in primary breast cancers. ER $\alpha$-negative primary breast cancers and cell lines showed increased Src levels and/or activity compared with $E R \alpha$-positive cancers and cells. ER $\alpha t_{1 / 2}$ was reduced in ER $\alpha$-negative cell lines. In both ER $\alpha$-positive and -negative cell lines, both proteasome and Src inhibitors increased ER $\alpha$ levels. Src inhibition impaired ligand-activated ER $\alpha$ ubiquitylation and increased ER $\alpha$ levels. Src siRNA impaired ligand-activated ER $\alpha$ loss in BT-20 cells. Pretreatment with Src increased ER $\alpha$ ubiquitylation and degradation in vitro. These findings provide what we believe to be a novel link between Src activation and ER $\alpha$ proteolysis and support a model whereby crosstalk between liganded ER $\alpha$ and Src drives ER $\alpha$ transcriptional activity and targets ER $\alpha$ for ubiquitin-dependent proteolysis. Oncogenic Src activation may promote not only proliferation, but also estrogen-activated $E R \alpha$ loss in a subset of $E R \alpha$-negative breast cancers, altering prognosis and response to therapy.
\end{abstract}

\section{Introduction}

Estrogen regulates the proliferation and development of tissues expressing estrogen receptors (ERs) and is a risk factor for breast cancer development. One-third of new breast cancers lack detectable $E R \alpha$ protein; these $E R \alpha^{-}$cancers have a worse prognosis than do $E R \alpha^{+}$breast cancers (1). $E R \alpha^{-}$breast cancers do not respond to hormone response modifiers like tamoxifen (2) and often show de novo or acquired resistance to chemotherapy (1). While there are 2 forms of ERs, ER $\alpha$ and ER $\beta$ (3-5), considerably more is known about the role of ER $\alpha$ in human breast cancer, and in this study we investigated ER $\alpha$ exclusively. While estrogen is mitogenic for cultured $\mathrm{ER} \alpha^{+}$breast cancer lines, $\mathrm{ER} \alpha^{-}$breast cancer lines proliferate in the absence of estrogen, and ER $\alpha^{-}$breast cancers are generally believed to be estrogen independent.

Factors responsible for the ER $\alpha^{-}$status of breast cancers remain largely unknown. Deletions, rearrangements, and point mutations in the ESR1 gene, which encodes ER $\alpha$, are too uncommon to account for the $E R \alpha^{-}$phenotype $(6,7)$. ER $\alpha$ promoter hypermethylation has been observed in a minority (up to $25 \%$ ) of ER $\alpha^{-}$breast carcinomas (6). In 3 early nonquantitative studies, ESR 1 mRNA was detected in a majority $(67 \%-71 \%)$ of 64 primary ER $\alpha^{-}$cancers (8-10), indicating posttranscriptional or posttranslational control of ER $\alpha$ levels in human breast cancers. Transcriptional profiling has demonstrated that ESR1 mRNA is detected but variably

Nonstandard abbreviations used: cFBS, charcoal-stripped FBS; CHX, cycloheximide; cSrc, cellular Src; ER, estrogen receptor; ERE, estrogen response element; HR, hormone receptor; LBA, ligand binding assay; PA, ponasterone A; PR, progesterone receptor; QPCR, quantitative real-time RT-PCR; RPPA, reverse phase tissue lysate array. Conflict of interest: The authors have declared that no conflict of interest exists. Citation for this article: J. Clin. Invest. 117:2205-2215 (2007). doi:10.1172/JCI21739. reduced in ER $\alpha^{-}$compared with $E R \alpha^{+}$cancers (11-13). The distinct gene expression profiles of $E R \alpha^{+}$and $E R \alpha^{-}$cancers have led to the hypothesis that these 2 tumor groups arise from different cellular origins: $E R \alpha^{-} / \mathrm{Her} 2^{-}$tumors are derived from the basal epithelium, while $E R \alpha^{+}$cancers have a luminal epithelial origin (14, 15). The results of our present study shed further light on mechanisms regulating ER $\alpha$ levels.

$\mathrm{ER} \alpha$ is a $66-\mathrm{kDa}$ nuclear hormone receptor (HR) transcription factor (16). Upon ligand binding, ER $\alpha$ dimerizes and associates with coactivators and chromatin remodeling factors to activate transcription of genes containing estrogen response elements (EREs) (17). ER $\alpha$ contains 2 transcription activation functions, AF-1 and AF-2. AF-1 can be phosphorylated and activated in a ligand-independent manner following growth factor stimulation, while AF-2 is activated by ligand-stimulated changes in ER $\alpha$ conformation $(18,19)$. The ER $\alpha$ phosphorylation state affects coactivator binding and ER $\alpha$-DNA binding affinity.

In addition to transcriptional activation, ligand-ER $\alpha$ binding rapidly activates crosstalk with mitogenic signaling kinases (reviewed in refs. 20,21). Estrogen-ER $\alpha$ binding promotes a rapid and transient interaction of ER $\alpha$ with cellular $\operatorname{Src}(\mathrm{cSrc})$, binding to Shc and Ras-MAPK activation (22-25). In some cell types, estrogen stimulates tripartite $\mathrm{ER} \alpha, \mathrm{cSrc}$, and PI3K complex formation, leading to PKB/AKT and MAPK activation (26). Signaling kinases activated by liganded ER $\alpha$ not only activate mitogenic cascades, but also phosphorylate the ER $\alpha$ and its coactivators, generating a feed-forward loop that augments ER $\alpha$ transcriptional activity $(20,21,27)$.

The ER $\alpha$ can also be phosphorylated and activated in a ligandindependent manner in response to peptide growth factors including IGF-I (28), TGF- $\alpha$ (29), and EGF $(30,31)$ that activate PKB and MAPK signaling pathways and cause ER $\alpha$ phosphorylation and 


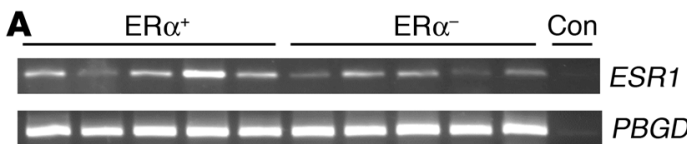

B
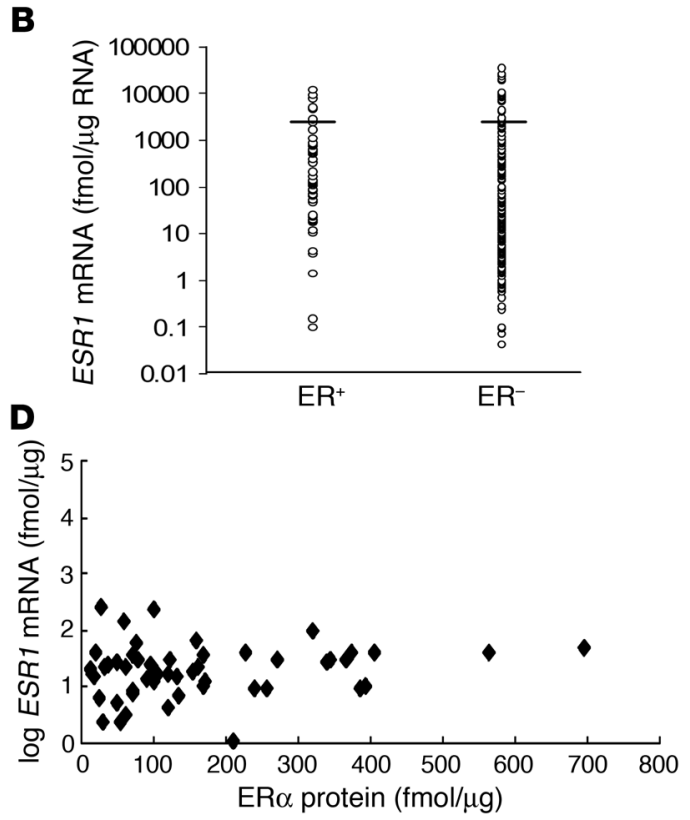
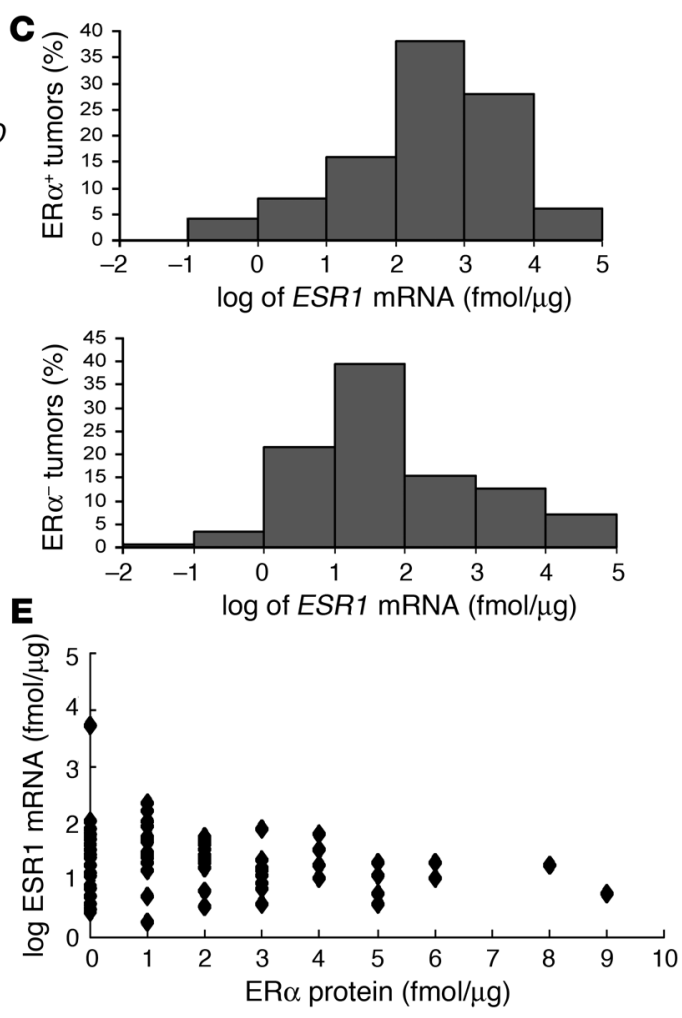

\section{Figure 1}

$E R \alpha^{-}$and $E R \alpha^{+}$human breast cancers express ESR1 mRNA. (A) PCR of ESR1 and human $P B G D$ from breast tumors. Blots are representative of 50 $E R \alpha^{+}$and $200 \mathrm{ER}^{-}$cancers. Con, control. (B) ESR1 mRNA concentrations. The horizontal line denotes the mean. (C) Frequency of ESR1 mRNA concentrations rounded to the nearest logarithm value. (D and $\mathbf{E})$ ESR1 mRNA (fmol/ $\mu \mathrm{g}$ total RNA) plotted versus ER $\alpha$ protein by LBA (fmol/ $\mu \mathrm{g}$ cytosolic protein) in the same human breast cancers.
ER $\alpha$-dependent gene transcription. Phosphorylation of aminoterminal $(30,32,33)$ and carboxyterminal (34-36) sites on the ER $\alpha$ increase $\mathrm{ER} \alpha$ transcriptional activity.

Estrogen binding to the ER $\alpha$ rapidly stimulates ER $\alpha$ ubiquitylation and proteolysis (37-39). Unliganded ER $\alpha$ is very stable, with a $t_{1 / 2}$ of up to 5 days (37). Upon ligand binding, the ER $\alpha t_{1 / 2}$ drops dramatically, to $3-5$ hours $(37,39)$. The detection of ubiquitinated ER $\alpha$ in vivo in uterine tissue (37) and the finding that proteasome inhibition abrogates estrogen-stimulated ER $\alpha$ loss confirmed an in vivo role for proteasome-mediated ER $\alpha$ degradation in regulating $\mathrm{ER} \alpha$ levels $(38,39)$.

$\mathrm{ER} \alpha$ ubiquitination and proteasome activity are intimately linked to ER $\alpha$-dependent transcriptional activation $(40,41)$. Ligand binding activates both ER $\alpha$-dependent transcription and ER $\alpha$ ubiquitination (40). Proteasome inhibitors and mutations that inhibit coactivator binding both abrogate ligand-mediated ER $\alpha$ proteolysis and ERE transcriptional activity (41). Different ligands stimulate ER $\alpha$ proteolysis to different degrees (42), and ubiquitin ligases BRCA1 (43), MDM2 (44), and E6AP (45) can all stimulate estrogen-induced transcriptional activity.

The $60-\mathrm{kDa}$ cSrc tyrosine kinase regulates cellular proliferation and motility as well as tumor metastasis (46). Increased levels and/or activity of cSrc have been observed in primary breast cancers (47), but to our knowledge, an association with ER $\alpha$ levels has not previously been reported. Here we demonstrate that both $E R \alpha^{+}$and $E R \alpha^{-}$primary human breast carcinomas expressed ESR1 mRNA. Crosstalk between liganded ER $\alpha$ and cSrc appeared to promote proteasomal degradation of the ER $\alpha$. cSrc inhibition impaired ligand-activated ER $\alpha$ ubiquitylation and $\mathrm{ER} \alpha$ proteolysis, while Src induction shortened the ER $\alpha t_{1 / 2}$. Src induction also increased ER $\alpha$-driven transcription. ER $\alpha^{-}$breast cancer specimens and cell lines showed elevated cSrc levels and/ or activity compared with ER $\alpha^{+}$tumors and cell lines, and ER $\alpha$ proteolysis was increased in ER $\alpha^{-}$cell lines. Src stimulated both ER $\alpha$ ubiquitylation and proteasome-dependent ER $\alpha$ degradation in vitro. These observations and the inverse correlation between cSrc and ER $\alpha$ levels in primary breast cancers suggest that Src may promote cell proliferation by stimulating transcription-coupled ER $\alpha$ degradation in human breast cancers.

\section{Results}

ER $\alpha^{-}$breast cancers express ESR $1 \mathrm{mRNA}$. ESR $1 \mathrm{mRNA}$ expression was quantitated in $200 \mathrm{ER} \alpha^{-}$and $50 \mathrm{ER} \alpha^{+}$primary human breast cancers. ER $\alpha$ protein levels were determined in a single clinical reference laboratory by ligand binding assay (LBA). Tumor ESR1 mRNA was quantitated by quantitative real-time RT-PCR (QPCR). Crossing-point values for each tumor sample were compared to a standard curve generated from serial dilutions of ER $\alpha$ cDNA plasmid (data not shown). Quantitation of housekeeping gene human porphobilinogen deaminase $(P B G D)$ expression demonstrated similar mRNA quality in both $E R \alpha^{+}$and $E R \alpha^{-}$breast cancers. ESR 1 mRNA was detected in all of $50 \mathrm{ER} \alpha^{+}$and $200 \mathrm{ER} \alpha^{-}$cancers (Figure 1A). The ESR1 mRNA values (Figure 1B) and distribution (Figure 1C) showed considerable variability and overlap in ESR1 mRNA concentrations in $\mathrm{ER} \alpha^{+}$and $\mathrm{ER} \alpha^{-}$tumors. The mean ESR1 mRNA concentration was $1.14 \times 10^{3} \mathrm{fmol} / \mu \mathrm{g}$ RNA in ER $\alpha^{+}$cancers (range, $1.02 \times 10^{-1}$ to $1.19 \times 10^{4} \mathrm{fmol} / \mu \mathrm{g}$ RNA) and $1.27 \times 10^{3} \mathrm{fmol} / \mu \mathrm{g}$ RNA in ER $\alpha^{-}$cancers (range, $4.55 \times 10^{-2}$ to $3.56 \times 10^{4} \mathrm{fmol} / \mu \mathrm{g}$ RNA). While the lowest and highest ESR 1 mRNA concentrations were similar and the mean ESR1 mRNA values did not differ significantly between the ER $\alpha^{+}$and $\mathrm{ER} \alpha^{-}$cancers $(P>0.50)$, the modal ESR1 mRNA value in the ER $\alpha^{-}$tumors was approximately $1 \log$ lower than in the $\mathrm{ER} \alpha^{+}$tumors. When ER $\alpha$ protein concentrations were graphed versus ESR1 mRNA values, there was no 


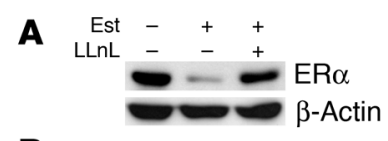

B

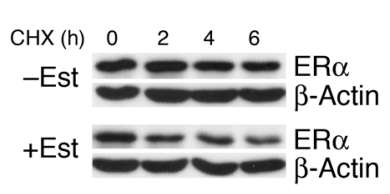

C

cresta
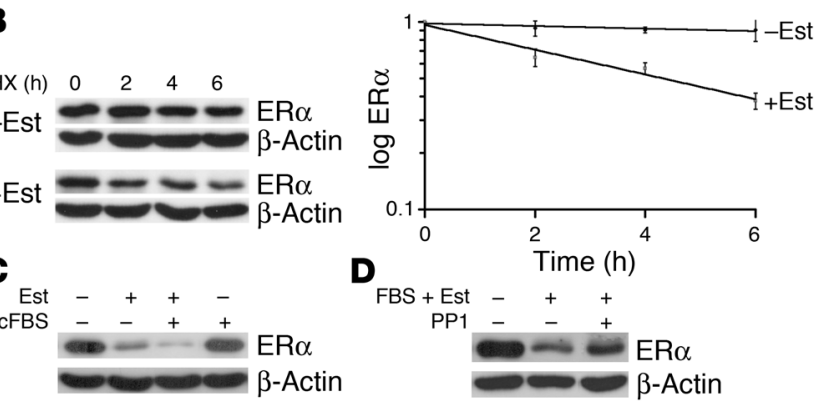

D

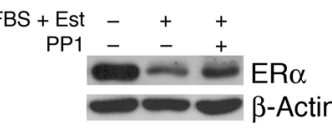

E
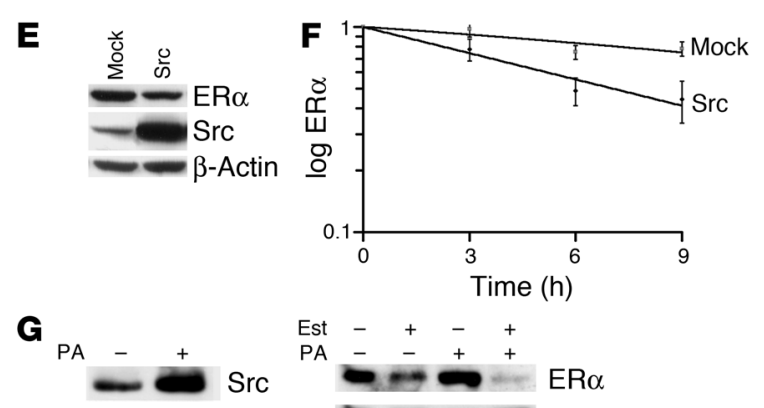

H
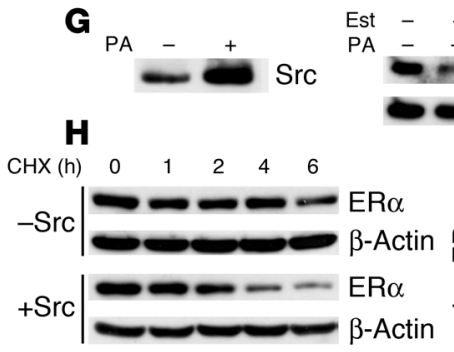

Time $(\mathrm{h})$

\section{Figure 2}

Src promotes estrogen-dependent ER $\alpha$ degradation. (A) ER $\alpha$ before and 6 hours after addition of estradiol (Est) with or without the proteasome inhibitor N-acetyl-Leu-Leu-norleucinal (LLnL) to estrogen-depleted MCF-7 cells. Equal loading was confirmed by $\beta$-actin. (B) ER $\alpha t_{1 / 2}$ was assayed by $\mathrm{CHX}$ chase in estrogendepleted cells and at 2, 4, and 6 hours after addition of estradiol. Graph shows results of densitometric analysis of $3 \mathrm{CHX}$ chase experiments (mean $\pm \mathrm{SEM}$ ). (C) Cells were grown in $0.1 \% \mathrm{cFBS}$ for 48 hours and then treated with estradiol alone, $5 \%$ cFBS plus estradiol, or $5 \%$ cFBS alone. ER $\alpha$ and $\beta$-actin were assayed 6 hours later. (D) Serum- and estrogen-deprived MCF-7 cells were transferred to $5 \%$ FBS plus estradiol with or without added Src inhibitor PP1, and ER $\alpha$ was assayed 6 hours later. (E and F) MCF-7 cells were transfected with PCI-Src Y530F (Src) or empty vector (Mock). After 24 hours, (E) ER $\alpha$ and Src levels were assayed and (F) ER $\alpha t_{1 / 2}$ was assayed by $\mathrm{CHX}$ chase (mean $\pm \mathrm{SEM}$ ). ( $\mathbf{G}$ and $\mathbf{H}$ ) The MCFpINDSrc2 line was estrogen depleted for 72 hours, and Src was induced or not for 24 hours with PA prior to addition of estradiol. (G) Src at time of estradiol addition (left), and ER $\alpha$ and $\beta$-actin before and 6 hours after estradiol (Est + or - ) was added (right). (H) CHX pulse chase, starting 6 hours after estradiol addition with $(+\mathrm{Src})$ or without $(-\mathrm{Src})$ prior induction of Src by PA. clear relationship between ER $\alpha$ protein and ESR1 mRNA levels for either $E R \alpha^{+}$or $E R \alpha^{-}$cancers (Figure 1, D and E).

Serum growth factors cooperate with estrogen to activate ER $\alpha$ proteolysis. As a baseline for further study, we showed that addition of $\beta$-estradiol, the primary estrogen type in humans, to estrogen-deprived MCF-7 cells stimulated a rapid reduction of ER $\alpha$ protein that was impaired by proteasome inhibition with $\mathrm{N}$-acetyl-Leu-Leu-norleucinal (Figure 2A). The ER $\alpha t_{1 / 2}$ was greater than 24 hours in estrogendepleted MCF-7 cells. Within 6 hours of estradiol addition, the ER $\alpha$ $t_{1 / 2}$ fell to 5 hours (Figure 2B). A significant reduction in ER $\alpha t_{1 / 2}$ was also noted within 1 hour of ligand addition (data not shown).

Crosstalk between cSrc, PI3K, and receptor tyrosine kinases and liganded $E R \alpha$ leads to ER $\alpha$ phosphorylation and activation of ER $\alpha$ transcriptional activity $(21,28)$. To determine whether crosstalk between $E R \alpha$ and signaling pathways may also modulate ligand-activated $E R \alpha$ proteolysis, we tested whether addition of growth factors would affect estrogen-stimulated ER $\alpha$ loss. MCF-7 cells were growth factor and estrogen deprived in $0.1 \%$ charcoal-stripped FBS (cFBS) for 48 hours. Estradiol together with 5\% cFBS reduced ER $\alpha$ levels more rapidly than did estradiol alone (Figure 2C). Growth factor stimulation with $5 \% \mathrm{cFBS}$ without added estradiol was not sufficient to trigger ER $\alpha$ proteolysis. Thus, serum growth factors may activate signaling kinases to promote estrogen-activated ER $\alpha$ proteolysis.

Src promotes estrogen-stimulated ER $\alpha$ degradation. Liganded ER $\alpha$ binds cSrc leading to cSrc activation (22). Treatment of MCF-7 cells with the Src inhibitor PP1 caused a dose-dependent accumulation of ER $\alpha$ over 48 hours (data not shown). PP1 also impaired the fall in ER $\alpha$ levels observed when estrogen- and growth factor-starved cells were transferred to serum together with estradiol (Figure 2D). Thus, cSrc may promote ligand-activated ER $\alpha$ proteolysis. Transfection of activated Src (PCI-Src Y530F) reduced ER $\alpha$ levels (Figure 2E). The $\mathrm{ER} \alpha t_{1 / 2}$ fell from 14 hours in asynchronously proliferating MCF-7 cells to 9 hours at 24 hours after Src transfection (Figure 2F).

To assay further the effect of Src on ER $\alpha$ stability, 2 different MCF-7 derivatives were generated to inducibly express activated Src-Y350F. Results of experiments using 1 of these Src inducible MCF-7 lines, designated MCFpINDSrc2, are described below. MCFPINDSrc2 cells were deprived of estradiol and growth factors for 72 hours. Src was induced by treatment with ponasterone A (PA) for 24 hours prior to addition of estradiol (Figure 2G, left). Induction of activated $\mathrm{Src}$ did not reduce ER $\alpha$ levels in the absence of estradiol. However, within 6 hours of estradiol addition, ER $\alpha$ levels were markedly lower in Src-induced cells (Figure 2G, right), and ER $\alpha t_{1 / 2}$ was reduced to 2.6 hours in cells stimulated by estradiol together with Src induction, compared with an ER $\alpha t_{1 / 2}$ of 8.1 hours in cells treated with estradiol alone (Figure $2 \mathrm{H}$ ). Treatment with PA alone did not reduce ER $\alpha t_{1 / 2}$ (data not shown). At 24 hours after Src induction, QPCR showed a modest increase in ESR1 mRNA expression compared with uninduced cells (data not shown); thus, the more rapid $\mathrm{ER} \alpha$ protein loss in estradiol-treated, 
A

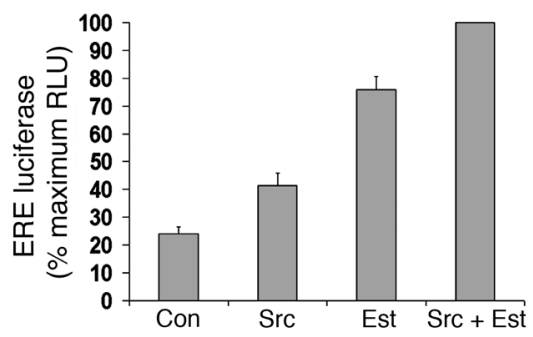

B

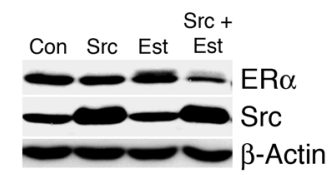

C

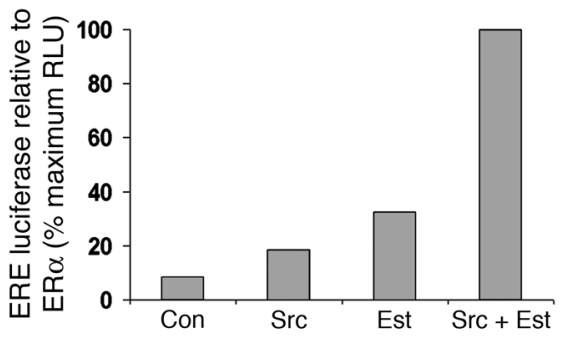

D

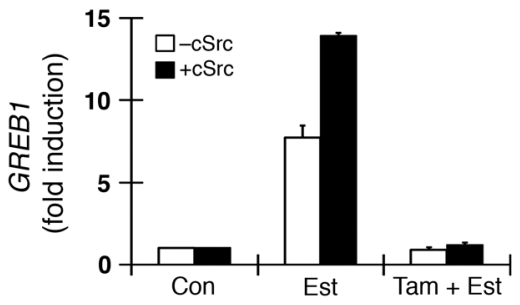

$\mathbf{E}$

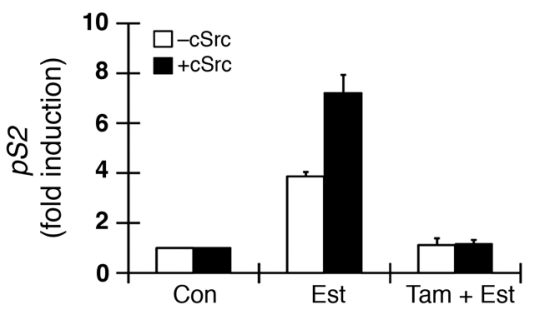

Src-induced cells was not due to reduced ESR1 mRNA expression. Data in a second Src-inducible cell line also confirmed these findings (data not shown). Thus, Src appears to cooperate with estrogen to stimulate ER $\alpha$ proteolysis. Proteasome inhibition reduced the effect of expression of activated Src (data not shown).

Src promotes ligand-activated ER $\mathrm{R}$ transcriptional activity. Activation of many transcriptional factors is linked to factor proteolysis (48). Because our data suggested that Src promotes ligand activated ER $\alpha$ proteolysis, we assayed effects of Src on ER $\alpha$ transcriptional activity. In cells grown in the presence of full serum and estradiol, addition of $10^{-8} \mathrm{M}$ estradiol and Src transfection each reproducibly increased ERE luciferase activity within 4 hours, albeit less notably with Src alone (Figure 3A). Estradiol addition together with Src transfection increased ERE luciferase activity beyond that induced by estradiol alone. Src transfection and estradiol stimulation also decreased ER $\alpha$ levels beyond that seen with estradiol alone (Figure 3B). For ERE luciferase activity relative to available ER $\alpha$ (i.e., correcting for the reduced $E R \alpha$ level at 4 hours), Src transfection and estradiol stimulation had more than additive effects (Figure 3C).

\section{Figure 3}

Src promotes estrogen-dependent ER $\alpha$ transcriptional activity. (A-C) MCF-7 was transfected with ERE luciferase reporter and either PClSrc Y530F or empty vector control and then stimulated with estradiol. Shown are (A) ERE luciferase activity as well as ER $\alpha$ and Src levels (B) before and (C) 4 hours after Src transfection, estradiol addition, or both. (C) Relative ERE luciferase activity corrected for ER $\alpha$ level. (D and E) MCFpINDSrc2 cells were estrogen depleted for 72 hours, and cSrc was induced or not for 24 hours prior to the addition of estradiol (Est) or estradiol plus tamoxifen (Est + Tam). (D and E) QPCR of cellular (D) GREB1 and (E) pS2.

To investigate further if Src affects estrogen-mediated transcription activity of ER $\alpha$, we used QPCR to quantitate estrogen stimulated expression of cellular ER $\alpha$ target genes, $p S 2$ and GREB1 with and without prior Src induction in the MCFPINDSrc2 line. MCFPINDSrc2 cells were estrogen deprived for 3 days, and Src was induced or not within the last 24 hours of starvation. Within 3 hours of estradiol addition, GREB1 and $p S 2$ mRNA levels increased by 8 - and 4-fold, respectively, compared with 14- and 7-fold higher than baseline when Src was inducted prior to estradiol addition. Src induction alone did not activate GREB1 or $p S 2$ (data not shown). Neither gene was activated when cells were treated with estradiol together with tamoxifen, with or without Src induction. Thus the effect of Src on these genes was ER $\alpha$ mediated, and Src increased the transcriptional potency of ER $\alpha$ on these ER $\alpha$ target genes (Figure 3, D and E).

$M E K$ and PI3K are not sufficient to promote ligand-mediated ER $\alpha$ proteolysis. MEK inhibition of asynchronous MCF-7 cells with U0126 for 48 hours reduced ER $\alpha$ levels (Supplemental Figure 1A; supplemental material available online with this article; doi:10.1172/ JCI21739DS1). In estrogen-deprived MCF-7 cells, MEK inhibition prior to estradiol addition led to a greater loss of ER $\alpha$ (Supplemental Figure 1B) and a shorter ER $\alpha t_{1 / 2}$ (data not shown) than with estradiol alone. Thus, in these assay conditions, MEK effectors appear to oppose ligand-stimulated $\mathrm{ER} \alpha$ proteolysis.

Treatment with the PI3K inhibitor LY294002 did not affect ER $\alpha$ levels in asynchronous MCF-7 cells (Supplemental Figure 1C). In estrogen-deprived MCF-7 cells, PI3K inhibition prior to estrogen repletion inhibited $\mathrm{PKB}$ phosphorylation and cell cycle progression, but did not affect estrogen-mediated ER $\alpha$ loss (Supplemental Figure 1, D and E). Thus, estrogen-stimulated ER $\alpha$ proteolysis does not require PI3K/PKB action or cell cycle entry.

$E R \alpha$ protein levels and stability are reduced in breast cancer lines with activated cSrc. The BT-20 breast cancer line shows both cSrc and EGFR activation, while Her 2 and cSrc are activated in MDA-MB361 (49). ESR1 mRNA was detected in MCF-7, BT-20, and MDAMB-361 by nonquantitative RT-PCR (data not shown). Although the BT-20 cell line has been characterized as ER $\alpha^{-}$, low but detectable $\mathrm{ER} \alpha$ protein was present on ER $\alpha$ immunoprecipitation from $1 \mathrm{mg}$ cell lysate (Figure 4A). cSrc kinase activities were increased (Figure 4B), while the level and $t_{1 / 2}$ of ER $\alpha$ were reduced in BT-20 and MDA-MB-361 compared with MCF-7 cells (Figure 4C). The calculated ER $\alpha t_{1 / 2}$ was 14 hours in asynchronous MCF-7, 9 hours in MDA-MB-361, and 5 hours in BT-20 cells.

To further assay effects of Src and proteasome function on ER $\alpha$ levels in ER $\alpha^{-}$breast cancer lines, the BT549 line was transfected with ER $\alpha$ to generate the stable line BT549-ER $\alpha$. Asynchronous BT549-ER $\alpha$ cells had elevated Src activity and the ER $\alpha t_{1 / 2}$ was 3.9 hours (data not shown). In both ER $\alpha^{+}$(MCF-7 and MDA-MB-361) 
A

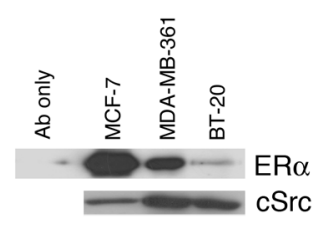

C

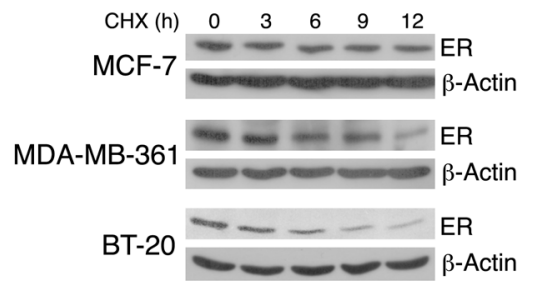

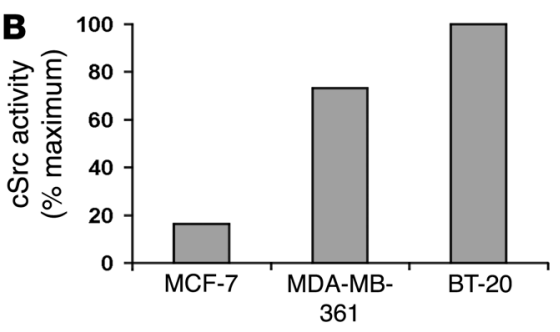
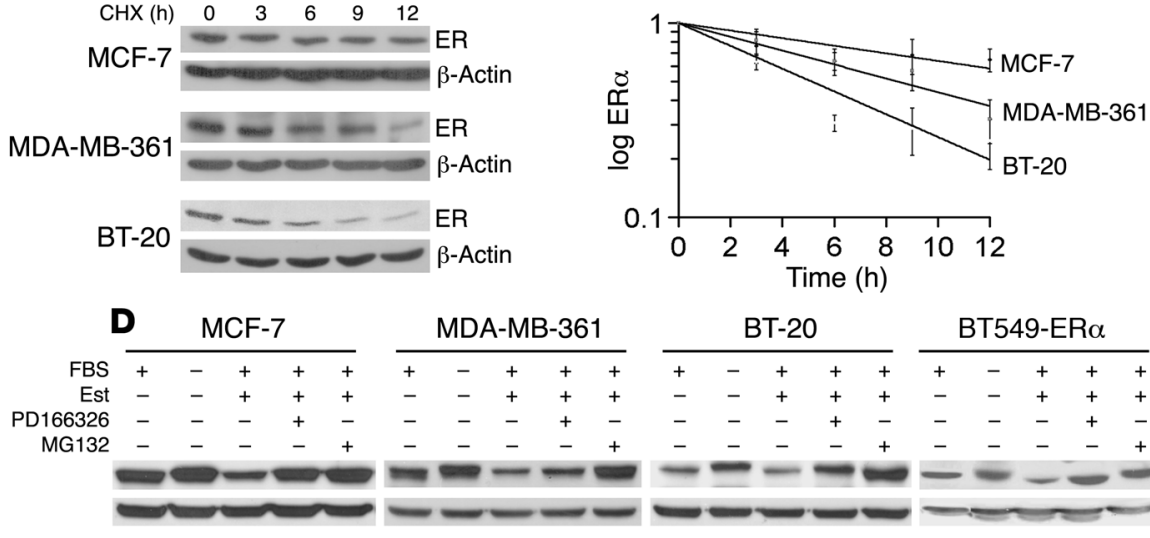

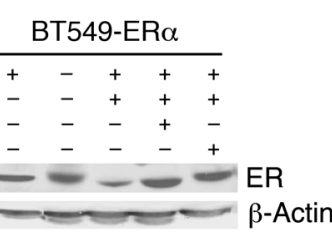

$\mathbf{E}$

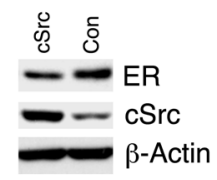

\section{Figure 4}

Estrogen regulation of $E R \alpha$ levels in $E R \alpha^{+}$and $E R \alpha^{-}$breast cancer lines. (A) $E R \alpha$ was detected by immunoblotting $E R \alpha$ precipitates from $1 \mathrm{mg}$ cell lysate of asynchronous ER $\alpha^{+}$MCF-7, MDA-MB-361, and ER $\alpha-B T-20$ cells. (B) cSrc activity in asynchronous MCF-7, MDA-MB-361, and BT-20 cells. (C) ER $\alpha t_{1 / 2}$ in asynchronous cells as assayed by CHX chase, calculated from 3 independent assays (mean \pm SEM). (D) After 48 hours serum and estrogen deprivation in $0.1 \%$ cFBS, MCF-7, MDA-MB-361, BT-20, and BT549-ER $\alpha$ cells were stimulated with estradiol plus $5 \%$ FBS with or without prior addition of MG132 or Src inhibitor PD166326, and ER $\alpha$ was assayed 6 hours later. (E) BT-20 cells were transfected with siRNA to cSrc or nonspecific control siRNA (Con) and deprived of estrogen for 48 hours. Cells were then treated with estradiol for 4 hours prior to Western blot analysis of cSrc and ER $\alpha$ levels.

and $\mathrm{ER} \alpha^{-}$(BT-20 and BT549-ER $\left.\alpha\right)$ lines, ER $\alpha$ levels increased with estrogen deprivation. Estradiol-stimulated ER $\alpha$ loss was impaired by proteasome inhibition with MG132 and also by Src inhibition with PD166326 (Figure 4D). For BT-20 cells, blots were exposed longer and more protein was loaded than for $E R \alpha^{+}$lines.

Because PD166326 inhibited Src and Src family kinases, we further tested the specific role of $\mathrm{Src}$ in $\mathrm{ER} \alpha$ regulation by transfecting BT-20 cells with either siRNA to Src or control siRNA and then depriving them of estrogen for 48 hours. Reduction of Src expression by Src siRNA impaired estrogen-stimulated ER $\alpha$ loss in BT-20 cells (Figure 4E). Thus Src appears to activate estrogen-stimulated $\mathrm{ER} \alpha$ proteolysis in both $\mathrm{ER} \alpha^{+}$and $\mathrm{ER} \alpha^{-}$breast lines.

Src inhibition impairs estrogen-stimulated ER $\alpha$ ubiquitylation in vivo. To test the effect of Src inhibition on ligand-driven ER $\alpha$ ubiquitylation, MCF-7 cells were estrogen deprived and then stimulated with estradiol with or without prior addition of the proteasome inhibitor MG132 or the Src inhibitor PP1. The ER $\alpha$ was immunoprecipitated from equal amounts of protein lysate, and complexes were resolved, immunoblotted with anti-ubiquitin antibody, and stripped and reprobed for total ER $\alpha$. ER $\alpha$ levels were maximal in estrogen-deprived cells. Although ER $\alpha$ levels were reduced 6 hours after estradiol stimulation, detection of ER $\alpha$ ubiquitylation was modestly increased. When estrogen-deprived cells were treated with estradiol and MG132, the ER $\alpha$ protein level remained elevated, and ubiquitylated ER $\alpha$ was readily detected (Figure 5A). In contrast, while Src inhibition with PP1 prevented estrogen-stimulated loss of the ER $\alpha$ protein and maintained high
$\mathrm{ER} \alpha$ protein levels, ER $\alpha$ ubiquitylation was minimal (Figure 5A). Thus, Src inhibition impaired ligand-activated ER $\alpha$ ubiquitylation and prevented ligand-mediated loss of ER $\alpha$.

Src activates ER $\alpha$ ubiquitylation and degradation in vitro. To assay the effect of Src on ER $\alpha$ ubiquitylation and degradation in vitro, recombinant ER $\alpha$ was pretreated with Src kinase or mock treated, after which equal amounts of $\mathrm{ER} \alpha$ were reacted with recombinant ubiquitin, ubiquitin-activating enzyme (E1), UbcH7 (E2), and E3 ubiquitin ligase supplied from asynchronous MCF-7 cell lysate. ER $\alpha$ was then precipitated and resolved, and ubiquitylated ER $\alpha$ was detected by immunoblotting with anti-ubiquitin antibody. In these assays, little ER $\alpha$ degradation occurred. Tyrosine phosphorylation of ER $\alpha$ was detected only in Src-treated samples. ER $\alpha$ ubiquitylation was enhanced by pre-treatment of the ER $\alpha$ with Src kinase (Figure 5B).

For ER $\alpha$ degradation, assay conditions were modified as described in Methods. Recombinant ER $\alpha$ was pretreated or not with Src kinase as above and then treated with the E1, E2, and E3 mixture with or without addition of $26 \mathrm{~S}$ proteasome fraction. ER $\alpha$ degradation was minimal in assays with Src or $26 \mathrm{~S}$ proteasome alone. When Src-pretreated ER $\alpha$ was incubated with E1, E2, and E3 together with 26S proteasome, ER $\alpha$ was completely degraded (Figure 5C).

cSrc is activated in ER $\alpha^{-}$primary breast cancers. cSrc kinase activity was assayed in lysates from $18 \mathrm{ER} \alpha^{-}$and $22 \mathrm{ER} \alpha^{+}$primary human breast cancers. The ER $\alpha$ status determined at diagnosis by LBA was verified by $E R \alpha$ immunoblotting. Blotting with $\beta$-actin verified equal loading and equal protein input in cSrc kinase assays. Elevated cSrc activity was observed in 78\% (14 of 18) of ER $\alpha^{-}$breast 


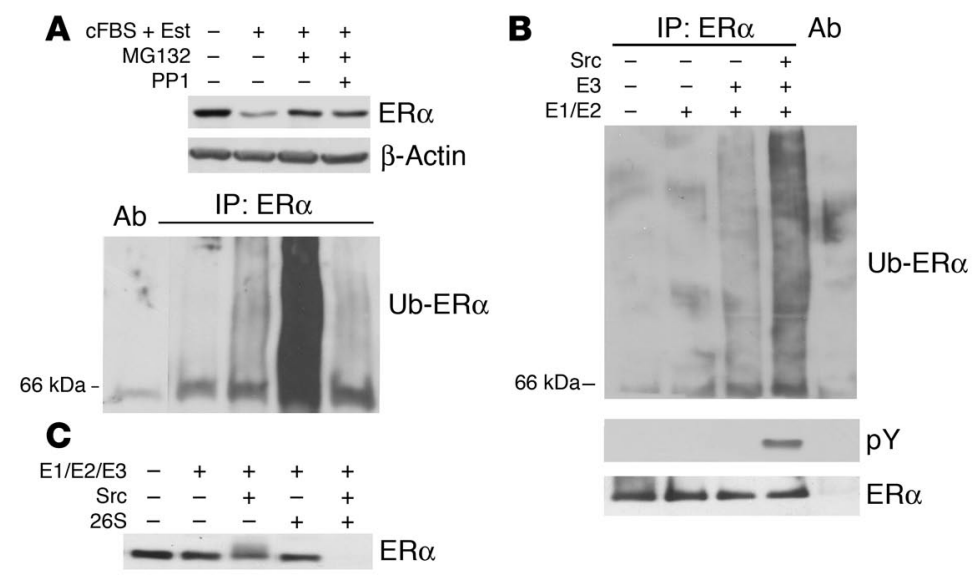

Figure 5

Src stimulates ER $\alpha$ ubiquitylation and degradation in vivo and in vitro. (A) Serum- and estrogen-deprived MCF-7 cells were treated with estradiol and $5 \%$ cFBS for 6 hours with or without immediate prior addition of MG132 or $\mathrm{PP} 1$, and $\mathrm{ER} \alpha$ levels were assayed. Equal loading was confirmed by $\beta$-actin. $\mathrm{ER} \alpha$ was precipitated, ER $\alpha$ complexes were resolved, and ubiquitylated $\mathrm{ER} \alpha$ $(\mathrm{Ub}-\mathrm{ER} \alpha$ ) was detected with anti-ubiquitin antibody. (B) For in vitro ER $\alpha$ ubiquitylation, recombinant $\mathrm{ER} \alpha$ protein was reacted with $\mathrm{E} 1$ and $\mathrm{E} 2$, with or without E3 and with or without prior treatment of ER $\alpha$ with Src kinase (as described in Methods), for 60 minutes. ER $\alpha$ immunoprecipitates were resolved and blotted with anti-ubiquitin or anti-phosphotyrosine ( $\mathrm{pY}$ ) antibodies. The membrane was stripped and reprobed for $\mathrm{ER} \alpha$. (C) In vitro degradation of recombinant $\mathrm{ER} \alpha$ used E1, E2, and E3 with or without prior incubation with Src and/or addition of 26S proteasome fraction as described in Methods.

cancers. In contrast, only $18 \%$ (4 of 22) of ER $\alpha^{+}$tumors showed Src activity above that of nonspecific antibody controls (Figure 6A).

Src and ER $\alpha$ levels are inversely correlated in primary buman breast cancers. To extend these findings, we quantitated ER $\alpha$ and Src protein expression by reverse phase tissue lysate array (RPPA) in 101 primary breast cancers using validated monospecific antibodies previously demonstrated to reflect Western blotting results with multiple tumor samples, providing a high-throughput quantitative analysis (50). Of 98 tumors in which the HR status was known, 68 were classified as positive for $\mathrm{ER} \alpha$ and/or progesterone receptor (PR) by immunohistochemistry in pathology evaluation at diagnosis. ER $\alpha$ quantified by RPPA was significantly higher in pathologic ER $\alpha^{+}$breast cancers $(P<0.001)$, as expected. Src protein was significantly higher in pathologic $E R \alpha^{-}$and $\mathrm{PR}^{-}(P=0.03)$ than in $\mathrm{HR}^{+}$tumors $\left(\mathrm{ER}^{+}\right.$and/or $\left.\mathrm{PR}^{+}\right)$. The distribution of Src values in $\mathrm{HR}^{+}$and $\mathrm{HR}^{-}$cancers is shown in Figure 6B. When $68 \mathrm{HR}^{+}$ tumors were compared with 23 "triple receptor-negative" tumors (ER $\alpha^{-}$and $\mathrm{PR}^{-}$by immunohistochemistry; HER2- by FISH), Src levels were highest in triple receptor-negative tumors $(P=0.02)$. In all tumors, quantified $\mathrm{ER} \alpha$ and Src expression were inversely correlated $(r=0.26, P=0.008$; Figure $6 \mathrm{C})$. In the subset of $68 \mathrm{HR}^{+}$ tumors, there was also a statistically significant inverse correlation between quantified expression of $\mathrm{ER} \alpha$ and $\operatorname{Src}(r=0.30 ; P=0.01)$.

\section{Discussion}

$\mathrm{ER} \alpha^{-}$breast cancers have distinct gene expression profiles and are clinically more aggressive than are $E R \alpha^{+}$cancers (12). The present study supports the hypothesis that, at least in a subset of ER $\alpha^{-}$ breast cancers, Src activation may drive estrogen-dependent ER $\alpha$ proteolysis. ESR1 gene alterations are too infrequent to explain the lack of detectable ER $\alpha$ protein in up to one-third of breast cancers $(6,7)$. Early studies indicated that as many as $60 \%-70 \%$ of ER $\alpha^{-}$tumors express ESR1 mRNA (8-10). More sensitive QPCR demonstrated ESR1 mRNA in all of $52 \mathrm{ER} \alpha^{-}$primary breast cancers (51). In the present analysis, all of $200 \mathrm{ER} \alpha^{-}$breast cancers expressed ESR 1 mRNA, with considerable variability and overlap in values in $E R \alpha^{+}$ and $E R \alpha^{-}$cancers. While mean ESR1 mRNA concentrations did not differ significantly between $E R \alpha^{+}$and $E R \alpha^{-}$cancers, the modal distribution of ESR1 mRNA concentrations was lower in $E R \alpha^{-}$cancers. This is consistent with results from microarray studies that compared individual tumor ESR1 mRNA to reference cRNA pooled from $E R \alpha^{+}$and $E R \alpha^{-}$ tumors $(11)$ or to the average signal from all tumors $(12,13)$ to reveal lower average $E S R 1$ gene expression in $E R \alpha^{-}$versus $\mathrm{ER} \alpha^{+}$cancers. The variability in ESR1 mRNA levels and the discordance observed between ESR1 mRNA and protein in both tumor types point to important posttranscriptional controls of ER $\alpha$ levels.

Up to one-third of primary breast cancers show HER2/ erbB-2 amplification, and a similar proportion has increased EGFR expression. Both are strongly associated with ER $\alpha^{-}$status $(52,53)$. Transfection of either EGFR or activated Her 2 can reduce ER $\alpha$ levels in MCF-7 cells, and this has been attributed to MAPK activation (54). However, both of these receptors activate Src. In breast cancer cells, cSrc binds phosphorylated Her2 or EGFR, promoting synergistic activation to stimulate breast cancer cell proliferation and survival (49). Indeed, Src inhibitors impair Her2- and EGFR-driven mitogenesis $(49,55)$. Src is also transiently recruited to and activated by estrogen-bound ER $\alpha$, leading to MAPK activation (22-25).

Src can phosphorylate ER $\alpha$ in vitro $(56,57)$. ER $\alpha$ phosphorylation by Src increases its affinity for estrogen (27), and may also affect ER $\alpha$-coactivator binding and transcriptional activity $(58,59)$. The present study indicates that Src can drive expression of certain ER $\alpha$ target genes, which suggests the presence of an important feed-forward signaling loop involving estrogen, the ER $\alpha$, and Src.

Crosstalk between liganded ER $\alpha$ and Src may not only regulate $\mathrm{ER} \alpha$ transcriptional activity, but also activate $\mathrm{ER} \alpha$ proteolysis. Inhibition of cellular Src impaired estrogen-mediated ER $\alpha$ ubiquitylation and ER $\alpha$ loss. Induced Src expression increased $p S 2$ and GREB1 expression and ligand-activated ER $\alpha$ proteolysis. In breast cancer lines, increased Src activity correlated with a shortened ER $\alpha$ $t_{1 / 2}$. In $E R \alpha^{+}$as well as $E R \alpha^{-}$lines, proteasome inhibition increased $\mathrm{ER} \alpha$ protein levels. Moreover, in both $\mathrm{ER} \alpha^{+}$and $\mathrm{ER} \alpha^{-}$lines, estrogen withdrawal increased ER $\alpha$ levels and estrogen-stimulated ER $\alpha$ loss was impaired by Src inhibition. Because the Src inhibitor drug used affects not only Src, but other Src family kinases, we tested the effect of specific Src siRNA on ER $\alpha$ levels in the BT-20 line. Downregulation of cSrc expression using siRNA reduced estrogen-stimulated ER $\alpha$ loss in BT-20 cells. While we cannot exclude a possible contribution of other Src family kinases to estrogen-driven ER $\alpha$ proteolysis, this Src siRNA data supports a role for Src itself in this action.

Src kinase assays showed cSrc activation in a majority of primary $\mathrm{ER} \alpha^{-}$tumors in a relatively small primary tumor set. In a larger group of over 100 primary breast cancers, Src protein levels correlated inversely with $\mathrm{ER} \alpha$ in both $\mathrm{ER} \alpha^{+}$and $\mathrm{ER} \alpha^{-}$tumors, as assayed by sensitive RPPA. ER $\alpha^{-}$cancers had higher Src levels than did $\mathrm{ER} \alpha^{+}$cancers, and this inverse statistical association was stronger 

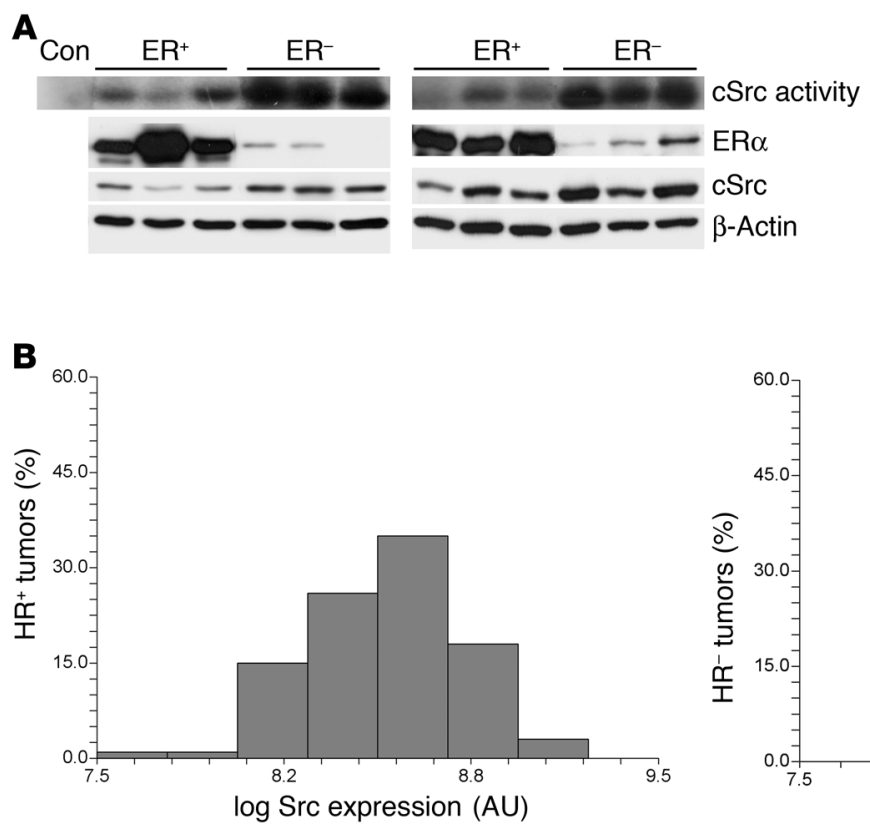
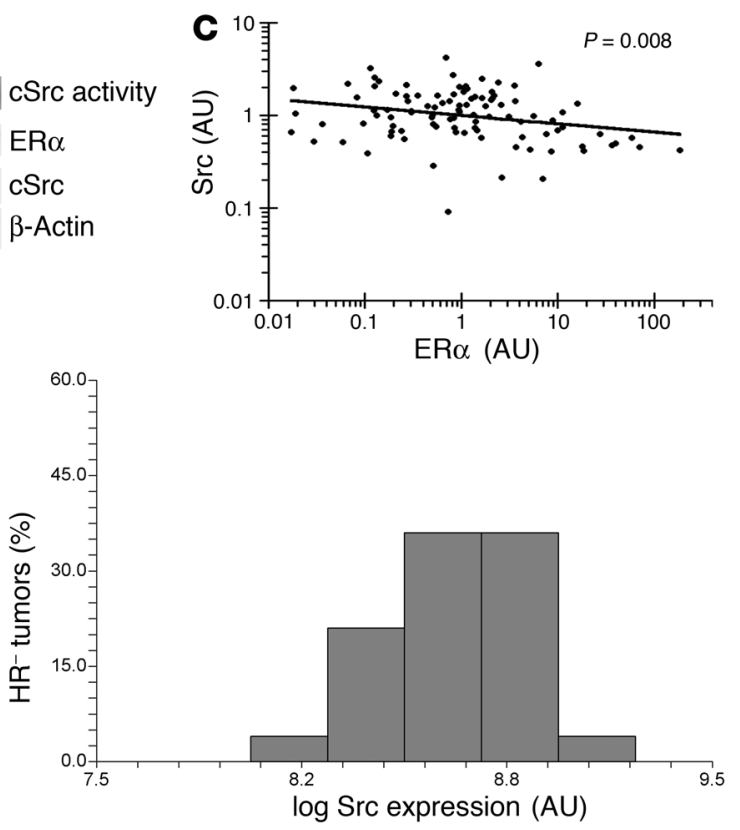

Figure 6

Elevation of cSrc activity and/or levels in ER $\alpha^{-}$primary breast cancers. (A) Cryopreserved breast tumors were lysed, ER $\alpha$ status was verified by Western blot, and cSrc kinase activity was assayed. Equal loading was confirmed by $\beta$-actin. Blots are representative of $22 \mathrm{ERa}+$ and 18 ERa- tumors. (B and C) ER $\alpha$ and Src protein levels were quantitated by RPPA in 101 primary breast cancers as described in Methods. (B) Histogram distribution of log Src protein levels (arbitrary units) rounded to nearest log for $\mathrm{HR}^{+}\left(\mathrm{ER} \alpha^{+}\right.$and/or $\left.\mathrm{PR}^{+}\right)$and $\mathrm{HR}^{-}\left(E R \alpha^{-}\right.$and $\left.\mathrm{PR}^{-}\right)$cancers. (C) Dot plot of Src and ER $\alpha$ protein values (expressed as log values, arbitrary units) in all cancers $(P=0.008)$.

in the subset of triple-negative compared with $\mathrm{ER} \alpha^{+}$tumors. These findings are consistent with our recent analysis of over 700 primary cancers in which the ER $\alpha^{-}$status correlated significantly $(P<0.001)$ with Src activation as detected by immunohistochemical staining for Y416-phosphorylated Src (A. Arnaout and J.M. Slingerland, unpublished observations). Although our data indicate that Src contributes to $\mathrm{ER} \alpha$ regulation in breast cancers, there are clearly a number of tumors with high Src levels that retain ER $\alpha$ protein as well as tumors with low ER $\alpha$ levels that do not have high Src levels or activity. Thus, additional Src-independent mechanisms may regulate ER $\alpha$ protein levels. Tumors with very low ESR1 mRNA levels may reflect ER $\alpha$ promoter methylation (6).

cSrc appears to promote the ubiquitylation of $\mathrm{ER} \alpha$ since $\mathrm{cSrc}$ inhibition impaired cellular ER $\alpha$ ubiquitylation and proteolysis in vivo. Moreover, ER $\alpha$ phosphorylation by Src increased both ER $\alpha$ ubiquitylation and 26S proteasome-mediated ER $\alpha$ degradation in vitro. These data support a model in which liganded $\mathrm{ER} \alpha$ recruits cSrc or cSrc-dependent kinases, leading to phosphorylation events that facilitate ER $\alpha$ binding to coactivators and/or components of the proteolytic machinery. Ligand- and Src-activated ER $\alpha$ ubiquitylation may be linked to transcriptional activation of a subset of ER $\alpha$-regulated genes. While our in vitro data support a direct effect, with Src phosphorylation of $\mathrm{ER} \alpha$ promoting its ubiquitindependent degradation, Src may also have indirect effects to promote ER $\alpha$ degradation. Src or its downstream effectors may also affect ligand-activated $\mathrm{ER} \alpha$ coactivator phosphorylation to regulate ER $\alpha$ degradation and transcriptional activity. SRC-3/AIB1 proteolysis accompanies estrogen-stimulated ER $\alpha$ activation (60). How specific Src-dependent ER $\alpha$ and/or coactivator phosphorylation events modulate the profile of coactivator binding, ERE selection, and ER $\alpha$ proteolysis will require further investigation. A recent report suggests that Src-mediated tyrosine phosphorylation may also regulate androgen receptor function (61).

Signaling pathways that activate many transcription factors, including c-Jun, c-Myc, and E2F-1, also trigger their ubiquitindependent degradation (48), thereby limiting transactivator function. Ubiquitylation is required for transcriptional activity of certain transcription factors $(48,62)$. Transcription factor ubiquitylation may influence coactivator/repressor binding (48), with coactivators subsequently enhancing ubiquitylation of certain transcription factors (63). Ligand-mediated proteolysis regulates turnover of most nuclear receptors (reviewed in ref. 64). Several ER $\alpha$ coactivators are also known to be ubiquitin ligases (43-45) or proteasome subunits (65).

In some models $(40,41)$, but not all $(66,67)$, proteasome inhibition decreases estrogen-ER $\alpha$ transcriptional activity despite an increase in ER $\alpha$ abundance. ESR1 mutations that impair coactivator binding abrogate ligand-stimulated ER $\alpha$ degradation (41). Thus, co-activator binding may regulate not only transcriptional activity but also ligand mediated ER $\alpha$ degradation. ER $\alpha$ cycles on and off the ERE $(40,68)$. Ligand increases the duration of ER $\alpha$ ERE binding and modifies ubiquitin ligase binding (40). Proteasome inhibition has been shown to dissociate ubiquitin-bound ER $\alpha$ from ERE motifs and reduce ER $\alpha$ transcriptional activity. Thus, for a subset of ER $\alpha$-driven genes, ER $\alpha$ ubiquitylation and transcription may be closely linked.

Cell type- and promoter-specific differences affect how ER $\alpha$ proteolysis influences target gene expression $(66,67)$. In one study, proteasome inhibition increased expression of cellular $p S 2$ and CTSD but decreased $P R$ expression (67). In certain promoter 
contexts, ligand-activated ER $\alpha$ may escape ubiquitylation and proteasomal degradation and yet remain functional. While proteolytic degradation of the ER $\alpha$ after ERE firing may allow reloading of the promoter, ubiquitylation and proteasomal degradation may potentially serve a more global role in regulating the abundance and overall activity of the ER $\alpha$. Moreover, constitutive ER $\alpha$ activation could potentially lead to reduced ER $\alpha$ levels as a result of constitutive ER $\alpha$ proteolysis.

ER $\alpha$ phosphorylation by different signaling pathways could theoretically promote recruitment of different coactivators or ubiquitin pathway components, changing both the profile of ER $\alpha$ targets expressed and the rate of ligand-stimulated ER $\alpha$ proteolysis in different tissues. During breast cancer progression, Src activation may alter coactivator binding, shifting ER $\alpha$ transcriptional targets to profiles that promote oncogenic change. The present data do not allow us to estimate the contribution of Src-mediated ER $\alpha$ transcriptional activity and degradation to the overall oncogenic effect of Src in breast cancer. While we speculate that the effects of Src on ER $\alpha$ signaling crosstalk and transcriptional activity may make an important contribution to its oncogenicity, further work is required to tease out the specific contribution to breast carcinogenesis of Src acting on ER $\alpha$.

$E R \alpha^{-}$breast cell lines are considered estrogen insensitive because they do not require estrogen for growth; coupled with the clinical observation that $\mathrm{ER} \alpha^{-}$breast cancers do not respond to tamoxifen (2), this led to the belief that ER $\alpha^{-}$tumors are estrogen independent. Our data raise the concern that at least a subset of $\mathrm{ER} \alpha^{-}$breast cancers, particularly those with oncogenic Src activation, may indeed be responsive to estrogen in vivo. Constitutive $\mathrm{ER} \alpha$ proteolysis in at least a subset of $E R \alpha^{-}$cancers may not reflect extinguished ER $\alpha$-dependent transcription, but rather indicate a shift to constitutive activation of different ER $\alpha$ transcriptional targets. The therapeutic implications of this work are potentially very significant and warrant further investigation.

\section{Methods}

Breast cancers used for ESR 1 mRNA quantitation. Cryopreserved primary invasive human breast cancers were obtained from the tumor repository of the Sunnybrook Health Sciences Center clinical ER $\alpha$ quantitation reference lab with approval from the Sunnybrook Health Sciences Center Review Ethics Board, Toronto, Ontario, Canada. One expert clinical biochemist performed all ER $\alpha$ cytosolic LBA (69). Concordance of ER $\alpha$ LBA with ER $\alpha$ immunohistochemistry was verified in 40 tumors.

RNA extraction and ESR 1 mRNA quantitation. mRNA was extracted from 300 macrodissected carcinomas (100 g) using TRIzol per the manufacturer's instructions (Molecular Research Center). All RNAs were visualized on ethidium gels. A total of 250 tumor RNA samples with an $\mathrm{OD}_{260} / \mathrm{OD}_{280}$ greater than 1.3 and less than 2.1 from $50 \mathrm{ER} \alpha^{+}$cancers ( $>30 \mathrm{fmol} / \mu \mathrm{g}$ protein by LBA) and $200 \mathrm{ER} \alpha^{-}$cancers ( $<10 \mathrm{fmol} / \mu \mathrm{g}$ protein by LBA) were analyzed. QPCR of human PBGD expression using the LightCycler hPBGD Housekeeping Gene Kit (Roche Applied Science) primer/hybridization mixture demonstrated similar expression and equal RNA quality in both groups (Student's $t$ test).

QPCR reactions used the LightCycler System (Roche Applied Science) and the QuantiTect SYBR Green RT-PCR kit (QIAGEN). Primers are listed in Supplemental Methods. A standard curve for ESR1 mRNA quantitation was generated using serial dilutions of full-length human ER $\alpha$ cDNA plasmid PCMV5hER- $\alpha$ (provided by B. Katzenellenbogen, University of Illinois, Urbana, Illinois, USA). MCF-7 ESR1 mRNA was quantitated using the PCMV5hER- $\alpha$ plasmid standard curve. MCF-7 mRNA was run as a positive control in all tumor ESR1 mRNA QPCR reactions. Tumor ESR1 mRNA values ranged from $10 \mathrm{fg} / \mu \mathrm{l}$ to $1 \mu \mathrm{g} / \mu \mathrm{l}$. Melting curve analysis ensured exclusion of primer dimmers from each analysis. ESR 1 mRNA concentrations in $E R \alpha^{+}$and $E R \alpha^{-}$cancers were compared by Student's $t$ test.

Sequencing of ER $\alpha$ cDNA PCR product. All tumor ER $\alpha$ PCR products were visualized by gel electrophoresis. For a subset, PCR-amplified ER $\alpha$ cDNA was gel extracted with QIAquick Gel Extraction Kit (QIAGEN), and $10 \mathrm{ng}$ DNA was sequenced using 3.2 pmol of each ER $\alpha$ sequencing primer, Terminator Reaction Mix (ABI Prism dGTP BigDye Terminator v3.0 Cycle Sequencing Ready Reaction Kit; Applied Biosystems), and the ABI Prism 3100 Genetic Analyzer (Applied Biosystems).

Cell culture. MCF-7 cells were grown in 5\% FBS, and estrogen was depleted in $5 \%$ cFBS for 48 hours as described previously (70). For depletion of both growth factors and estrogen, cells were transferred to $0.1 \% \mathrm{cFBS}$ for 48 hours. The ER $\alpha^{-}$BT-20 and BT549 cell lines and the weakly ER $\alpha^{+}$ MDA-MB-361 cell line (provided by S. Parsons) were grown in DMEM (49). The identity of $E R \alpha^{+}$and $E R \alpha^{-}$lines was confirmed by karyotyping. To assay effects of growth factors on ER $\alpha$ levels, $10 \mathrm{nM} \beta$-estradiol with or without $5 \%$ FBS or $5 \%$ cFBS alone was added to MCF-7 cells that had been estrogen and growth factor depleted for 48 hours; ER $\alpha$ levels were assayed 1-6 hours later.

Plasmids and transfection. Activated human cSrc vector, PCI-Src Y530F (from D. Fujita, University of Calgary, Calgary, Alberta, Canada) or empty PCI $(10 \mu \mathrm{g})$ was transfected into MCF-7 cells using lipofectamine PLUSTM (Invitrogen). BT549 cells were transfected with PCMV5hER- $\alpha$, and stable lines were cloned.

Construction of MCF-7 lines with inducible Src expression. Src Y530F cDNA was cloned into PIND and transfected into the MCF-7 line with an integrated $\mathrm{pVgRXR}$ vector (Invitrogen). Src was induced with $2 \mu \mathrm{M}$ PA. MCFpINDSrc2 cells had high Src induction 8-24 hours after induction with PA. This line was estrogen deprived as described above for 72 hours, and $2 \mu \mathrm{M}$ PA was added or not for the last 24 hours of estrogen deprivation. Cells were then transferred to $0.1 \% \mathrm{cFBS}, 10 \mathrm{nM}$ estradiol was added for 6 hours, and ER $\alpha t_{1 / 2}$ was assayed by cycloheximide (CHX) chase as described below.

Flow cytometric analysis. BrdU pulse labeling and flow cytometric analysis were performed as described previously (70).

Antibodies. The ER $\alpha$ mAb H222 was supplied by G. Greene (University of Chicago, Chicago, Illinois, USA), ER $\alpha$ antibody HC-20 and anti-ubiquitin antibody P4D1 were from Santa Cruz Biotechnology Inc., and antiSrc mAb GD11 was from Upstate Biotechnology. Antibodies to MAPK, phosphosphorylated MAPK, total PKB, and activated PKB as well as antiphosphotyrosine antibody P-tyr-102 were from Cell Signaling; antibody to $\beta$-actin was from Sigma-Aldrich.

Immunoblotting and $\mathrm{CHX}$ chase. Cells were lysed in ice-cold D/RB buffer (50 mM HEPES, pH 7.5; 150 mM NaCl; 1 mM EDTA, pH 8.0; 2.5 mM EGTA, $\mathrm{pH} 8.0 ; 10 \%$ glycerol; $10 \mathrm{mM} \beta$-glycerophosphate; $1 \mathrm{mM} \mathrm{NaF}$; $0.1 \%$ Tween-20; $1 \mathrm{mM}$ PMSF; $0.1 \mathrm{mM} \mathrm{Na} \mathrm{VO}_{4} ; 0.5 \mathrm{mM}$ DTT; and $0.02 \mathrm{mg} / \mathrm{ml}$ each of aprotinin, leupepsin, and pepstatin). Protein was quantitated by Bradford protein assay. Western blots used $20-100 \mu$ g protein per lane. The ER $\alpha t_{1 / 2}$ was determined by CHX chase, with addition of $100 \mu \mathrm{g}$ CHX considered $t=0$. Cells were lysed at the times indicated in Figures 2 and 4, and ER $\alpha$ was blotted. ER $\alpha$ protein was quantitated by densitometry from 3 experiments using ImageQuant imaging system (version 5.2; GE Healthcare).

Effects of MEK and PI3K inhibition on ER $\alpha$ stability. To assay effects of MEK or PI3K inhibition on ER $\alpha$ levels, increasing concentrations of UO126

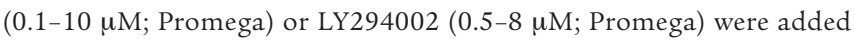
to asynchronous MCF-7 cells for 48 hours prior to immunoblotting or flow cytometry. Estrogen- and growth factor-depleted MCF-7 cells were treated with either $10 \mu \mathrm{M}$ UO126 or $8 \mu \mathrm{M} \mathrm{LY} 294002$ for 30 minutes prior 
to stimulation with $17 \beta$-estradiol for 6 hours, followed by immunoblotting and flow cytometry.

Cellular Src kinase assays. Cell lines or primary human breast cancers were lysed in ice-cold NP40 lysis buffer (70) with added $0.1 \mathrm{mM} \mathrm{Na}_{2} \mathrm{VO}_{4}$ and $1 \mathrm{mM}$ EDTA (pH 8.0). Src was precipitated from $200 \mu \mathrm{g}$ lysate, and Src kinase was assayed as described previously (71).

ERE luciferase assays. MCF-7 cells were transfected with $500 \mathrm{ng}$ of plasmid bearing 2 tandem ERE ( $2 \times$ ERE luc), $50 \mathrm{ng}$ phRL-TK luc, and $100 \mathrm{ng}$ cSrc-Y530F using Lipofectamine Plus (Invitrogen) per the manufacturer's instructions. Cells were treated with $10 \mu \mathrm{M}$ PP1 and/or $10 \mathrm{nM}$ estradiol for 4 hours prior to luciferase assays using dual-luciferase reporter assays (Promega) and Beckman Coulter LD400 Luminscence Detector.

QPCR of ER $\alpha$ target genes $P S 2$ and GREB1. MCFPINDSrc2 cells were maintained in $5 \% \mathrm{cFBS}$ for 2 days before adding $2 \mu \mathrm{M}$ PA for 24 hours to induce Src. The cells - with and without Src induction - were then treated with either $10 \mathrm{nM} \beta$-estradiol or $100 \mathrm{nM}$ tamoxifen plus estradiol for 3 hours. Total RNA was isolated using TRIzOL according to the manufacturer's instructions (Invitrogen). cDNA synthesis was performed with $1 \mu \mathrm{g}$ total RNA using iScript cDNA kit (Bio-Rad). QPCR was performed using icycleriQ PCR detection system (Bio-Rad) with $10 \mathrm{ng}$ cDNA sample in iQ SyberGreen supermix (Bio-Rad). PCR conditions and primers are described in Supplemental Methods.

SiRNA-mediated inbibition of cSrc expression. Dharmacon ON-TARGET plus SMARTpool siRNA reagent (Thermo Fisher Scientific) targeting cSrc and siCONTROL Non-Targeting siRNA Pools (Dharmacon; Thermo Fisher Scientific) were transfected into BT-20 cells cultured in media with $5 \%$ FBS using Lipofectamine 2000 (Invitrogen) for 4 hours. The cells were then estrogen deprived by transfer to media containing $5 \% \mathrm{cFBS}$ for 48 hours. Cells were then treated with estradiol or not for 4 hours prior to lysis for analysis of ER $\alpha$ and Src levels by Western blotting.

Detection of ER $\alpha$ ubiquitylation in vivo. MCF-7 cells were starved in $0.1 \% \mathrm{cFBS}$ for 48 hours and then either maintained in $0.1 \%$ cFBS or transferred to $5 \%$ cFBS medium with $10 \mathrm{nM}$ estradiol with or without $10 \mu \mathrm{M}$ PP1 or $10 \mu \mathrm{M}$ MG132. Six hours after estradiol addition, cells were lysed in $50 \mathrm{mM}$ Tris $(\mathrm{pH}$ 7.5), $150 \mathrm{mM} \mathrm{NaCl}, 10 \%$ glycerol, $2 \mathrm{mM}$ EDTA, $50 \mathrm{mM} \mathrm{NaF}, 1 \% \mathrm{NP} 40$, and $1 \%$ SDS; boiled for 10 minutes; and centrifuged for 1 minute at $14,000 \mathrm{~g}$ at $22^{\circ} \mathrm{C}$. Supernatant protein was quantitated, and $\mathrm{ER} \alpha$ and $\beta$-actin were assayed by Western blot. To detect ubiquitylated ER $\alpha, E R \alpha$ was immunoprecipitated from $500 \mu \mathrm{g}$ lysate, resolved by SDS-PAGE, and transferred to nitrocellulose (Bio-Rad). The membrane was boiled in transfer buffer for 10 minutes and immunoblotted with antibody against $\mathrm{ER} \alpha$ or ubiquitin.

In vitro ER $\alpha$ ubiquitylation assay. Ubiquitylation assays used $40 \mathrm{ng}$ recombinant ER $\alpha$ (Sigma-Aldrich), GST-ubiquitin-activating enzyme (E1), GSTubiquitin-conjugating enzyme UbcH7 (E2), MCF-7 lysate (50 $\mu \mathrm{g})$ as E3 source, and an energy regenerating solution (Boston Biochem) in $7.4 \mathrm{mM}$ HEPES (pH 7.4), $5 \mathrm{mM} \mathrm{KCl}$, and $1.5 \mathrm{mM} \mathrm{MgCl}_{2}$ for 60 minutes at $37^{\circ} \mathrm{C}$. Prior to ubiquitylation assays, recombinant ER $\alpha$ was either incubated with 10 ng recombinant Src kinase (Upstate) or mock-treated for 5 minutes at $30^{\circ} \mathrm{C}$ in $7.4 \mathrm{mM}$ HEPES (pH 7.4), $5 \mathrm{mM} \mathrm{KCl}$, and $1.5 \mathrm{mM} \mathrm{MgCl}_{2}$. ER $\alpha$ was precipitated, and complexes were resolved and transferred to nitrocellulose (0.45 $\mu \mathrm{m}$; Bio-Rad). The membrane was boiled for 10 minutes, and ER $\alpha$ and ubiquitylated ER $\alpha$ were detected as described above.
In vitro ER $\alpha$ degradation assay. ER $\alpha$ degradation assays used E1, E2, and E3 as described above, with the following modifications. To catalyze in vitro degradation of $\mathrm{ER} \alpha, 50 \mathrm{nM}$ of $26 \mathrm{~S}$ proteasome fraction (Boston Biochem) was added for 30 minutes at $37^{\circ} \mathrm{C}$ in $7.4 \mathrm{mM}$ HEPES ( $\mathrm{pH} 7.4$ ), $5 \mathrm{mM} \mathrm{KCl}$, $1.5 \mathrm{mM} \mathrm{MgCl}_{2}$, and $1 \mathrm{mM} \mathrm{DTT}$. ER $\alpha$ was assayed by Western blot.

$R P P A$. A total of 101 fresh-frozen primary breast tumors from the University of Texas MD Anderson Cancer Center Breast Tissue Tumor Bank were obtained with approval of the Institutional Review Board of the University of Texas MD Anderson Cancer Center. Tumors were macrodissected and lysed as described previously (50) and boiled in 1\% SDS, and protein-rich supernatants were serially diluted manually. A robotic GeneTAC arrayer (Genomic Solutions) created arrays of 62 -fold serial dilutions for each tumor lysate on nitrocellulose-coated glass slides (FAST Slides; Schleicher \& Schuell). Arrayed slides were probed with ER $\alpha$ antibody (NeoMarkers) and Src (Upstate), and the signal was amplified using a DakoCytomation catalyzed system. A secondary antibody (anti-rabbit) was used as a starting point for signal amplification. The slides were scanned and each protein in each sample was assigned a relative quantification value in arbitrary units using MicroVigene software (version 2.0; Vigene Tech). All samples were normalized for protein loading as described previously $(50,72)$. NCSS software (2004 version; NCSS) was used for 2-tailed Student's $t$ tests and canonical correlation. ER $\alpha$ and/or PR were assayed by immunohistochemistry in pathology evaluation at diagnosis.

Statistics. Differences in ESR1 and PBGD mRNA, quantitated by QPCR in the fresh frozen $E R \alpha^{+}$and $E R \alpha^{-}$breast cancer samples, were analyzed statistically using the Student's $t$ test. The relationship between Src kinase activity and ER $\alpha$ protein status (positive or negative) in 40 primary breast cancers was determined using the Student's $t$ test. For the RPPA analysis, the arbitrary units expressing ER $\alpha$ and Src protein levels were converted to logarithms and the relationship between ER $\alpha$ and Src protein levels was analyzed using 2-tailed Student's $t$ tests and canonical correlation. $P$ values of less than 0.05 were considered statistically significant.

\section{Acknowledgments}

We thank G. Greene for mAb H222 and D. Fujita for PCI-Src Y530F and S. Parsons for BT-20 and MDA-MB-361 cell lines. I. Chu was supported by a University of Toronto Medical Oncology Post-Graduate Award and by U.S. Department of Defense grant W81XWH-04-0392. A. Arnaout was supported by a Canadian Breast Cancer Foundation Physician Fellowship. J.M. Slingerland is supported by the Braman Family Breast Cancer Institute of University of Miami Sylvester Comprehensive Cancer Center.

Received for publication March 29, 2004, and accepted in revised form May 8, 2007.

Address correspondence to: Joyce M. Slingerland, Braman Family Breast Cancer Institute, University of Miami Miller School of Medicine, Batchelor Building, 4th Floor, Room 419, 1580 NW 10th Avenue, Miami, Florida 33136, USA. Phone: (305) 243-7265; Fax: (305) 243-4787; E-mail: jslingerland@med.miami.edu.
1. Jordan, V.C. 1995. Studies on the estrogen receptor in breast cancer -20 years as a target for the treatment and prevention of cancer. Breast Cancer Res. Treat. 36:267-285.

2. Clarke, M., et al. 1998. Tamoxifen for early breast cancer: an overview of the randomised trials. Lancet. 351:1451-1467.

3. Green, S., et al. 1986. Cloning of the human oestrogen receptor cDNA. J. Steroid Biochem. 24:77-83.
4. Kuiper, G.G., Enmark, E., Pelto-Huikko, M., Nilsson, S., and Gustafsson, J.A. 1996. Cloning of a novel receptor expressed in rat prostate and ovary. Proc. Natl. Acad. Sci. U. S. A. 93:5925-5930.

5. Mosselman, S., Polman, J., and Dijkema, R. 1996. ER-beta: identification and characterization of a novel human estrogen receptor. FEBS Lett. 392:49-53.

6. Ferguson, A.T., and Davidson, N.E. 1997. Regula- tion of estrogen receptor alpha function in breast cancer. Crit. Rev. Oncog. 8:29-46.

7. Roodi, N., et al. 1995. Estrogen receptor gene analysis in estrogen receptor-positive and receptornegative primary breast cancer. J. Natl. Cancer Inst. 87:446-451.

8. Carmeci, C., deConinck, E.C., Lawton, T., Bloch, D.A., and Weigel, R.J. 1997. Analysis of estrogen receptor messenger RNA in breast carcinomas from 
archival specimens is predictive of tumor biology. Am. J. Pathol. 150:1563-1570.

9. Henry, J.A., Nicholson, S., Farndon, J.R., Westley, B.R., and May, F.E.B. 1988. Measurement of oestrogen receptor mRNA levels in human breast tumours. Br. J. Cancer. 58:600-605

10. Garcia, T., Lehrer, S., Bloomer, W.D., and Schachter, B. 1988. A variant estrogen receptor messenger ribonucleic acid is associated wity reduced levels of estrogen binding in human mammary tumors. Mol. Endocrinol. 2:785-791.

11. van 't Veer, L.J., et al. 2002. Gene expression profiling predicts clinical outcome of breast cancer. Nature. 415:530-536.

12. Gruvberger, S., et al. 2001. Estrogen receptor status in breast cancer is associated with remarkably distinct gene expression patterns. Cancer Res. 61:5979-5984

13. West, M., et al. 2001. Predicting the clinical status of human breast cancer by using gene expression profiles. Proc. Natl. Acad. Sci. U. S. A. 98:11462-11467.

14. Perou, C.M., et al. 2000. Molecular portraits of human breast tumours. Nature. 406:747-752.

15. Sorlie, T., et al. 2001. Gene expression patterns of breast carcinomas distinguish tumor subclasses with clinical implications. Proc. Natl. Acad. Sci. U. S. A. 98:10869-10874

16. Nilsson, S., and Gustafsson, J.A. 2000. Estrogen receptor transcription and transactivation: basic aspects of estrogen action. Breast Cancer Res. 2:360-366.

17. Klinge, C.M. 2000. Estrogen receptor interaction with co-activators and co-repressors. Steroids. 65:227-251.

18. Tora, L., et al. 1989. The human estrogen receptor has two independent nonacidic transcriptional activation functions. Cell. 59:477-487.

19. Danielian, P.S., White, R., Lees, J.A., and Parker, M.G. 1992. Identification of a conserved region required for hormone dependent transcriptional activation by steroid hormone receptors. EMBOJ. 11:1025-1033.

20. Hall, J.M., Couse, J.F., and Korach, K.S. 2001. The multifaceted mechanisms of estradiol and estrogen receptor signaling. J. Biol. Chem. 276:36869-36872.

21. Coleman, K.M., and Smith, C.L. 2001. Intracellular signaling pathways: nongenomic actions of estrogens and ligand-independent activation of estrogen receptors. Front. Biosci. 6:D1379-D1391.

22. Migliaccio, A., et al. 1996. Tyrosine kinase/p21ras/ MAP-kinase pathway activation by estradiol receptor complex in MCF-7 cells. EMBO J. 15:1292-300.

23. Song, R.X., et al. 2004. The role of Shc and insulinlike growth factor 1 receptor in mediating the translocation of estrogen receptor a to the plasma membrane. Proc. Natl. Acad. Sci. U. S. A. 101:2076-2081.

24. Migliaccio, A., et al. 2000. Steroid-induced androgen receptor-oestradiol receptor beta-Src complex triggers prostate cancer cell proliferation. EMBOJ. 19:5406-5417.

25. Wong, C.W., McNally, C., Nickbarg, E., Komm, B.S., and Cheskis, B.J. 2002. Estrogen receptor-interacting protein that modulates its nongenomic activity-crosstalk with Src/Erk phosphorylation cascade. Proc. Natl. Acad. Sci. U. S. A. 99:14783-14788.

26. Castoria, G., et al. 2001. PI3-kinase in concert with Src promotes the S-phase entry of oestradiol-stimulated MCF-7 cells. EMBO J. 20:6050-6059.

27. Likhite, V.S., Stossi, F., Kim, K., Katzenellenbogen, B.S., and Katzenellenbogen, J.A. 2006. Kinasespecific phosphorylation of the estrogen receptor changes receptor interactions with ligand, DNA, and coregulators associated with alterations in estrogen and tamoxifen activity. Mol. Endocrinol. 20:3120-3132.

28. Aronica, S.M., and Katzenellenbogen, B.S. 1993. Stimulation of estrogen receptor-mediated transcription and alteration in the phosphorylation state of the rat uterine estrogen receptor by estrogen, cyclic adenosine monophosphate, and insulinlike growth factor-I. Mol. Endocrinol. 7:743-752.

29. Bunone, G., Briand, P.A., Miksicek, R.J., and Picard, D. 1996. Activation of the unliganded estrogen receptor by EGF involves the MAP kinase pathway and direct phosphorylation. EMBO J. 15:2174-2183.

30. Kato, S., et al. 1995. Activation of the estrogen receptor through phosphorylation by mitogenactivated protein kinase. Science. 270:1491-1494.

31. Ignar-Trowbridge, D.M., et al. 1992. Coupling of dual signaling pathways: epidermal growth factor action involves the estrogen receptor. Proc. Natl. Acad. Sci.U. S. A. 89:4658-4662.

32. Simoncini, T., et al. 2000. Interaction of oestrogen receptor with the regulatory subunit of phosphatidylinositol-3-OH kinase. Nature. 407:538-541.

33. Joel, P.B., et al. 1998. pp90rsk1 regulates estrogen receptor-mediated transcription through phosphorylation of SER-167. Mol. Cell. Biol. 18:1978-1984.

34. Yudt, M.R., et al. 1999. Function of estrogen receptor tyrosine 537 in hormone binding, DNA binding, and transactivation. Biochemistry. 38:14146-14156.

35. Arnold, S.F., Melamed, M., Vorojeikina, D.P. Notides, A.C., and Sasson, S. 1997. Estradiol-binding mechanism and binding capacity of the human estrogen receptor is regulated by tyrosine phosphorylation. Mol. Endocrinol. 11:48-53.

36. Weis, K.E., Ekena, K., Thomas, J.A., Lazennec, G., and Katzenellenbogen, B.S. 1996. Constitutively active human estrogen receptors containing amino acid substitutions for tyrosine 537 in the receptor protein. Mol. Endocrinol. 10:1388-1398.

37. Nirmala, P.B., and Thampan, R.V. 1995. Ubiquitination of the rat uterine estrogen receptor: dependence on estradiol. Biochem. Biophys. Res. Commun. 213:24-31.

38. Nawaz, Z., Lonard, D.M., Dennis, A.P., Smith, C.L. and O'Malley, B.W. 1999. Proteasome-dependent degradation of the human estrogen receptor. Proc. Natl. Acad. Sci. U. S. A. 96:1858-1862.

39. Alarid, E.T., Bakopoulos, N., and Solodin, N. 1999. Proteasome-mediated proteolysis of estrogen receptor: a novel component in autologous Downregulation. Mol. Endocrinol. 13:1522-1534.

40. Reid, G., et al. 2003. Cyclic, proteasome-mediated turnover of unliganded and liganded ERalpha on responsive promoters is an integral feature of estrogen signaling. Mol. Cell. 11:695-707.

41. Lonard, D.M., Nawaz, Z., Smith, C.L., and O'Malley, B.W. 2000. The $26 \mathrm{~S}$ proteasome is required for estrogen receptor-alpha and coactivator turnover and for efficient estrogen reeptor-alpha transactivation. Mol. Cell. 5:939-948.

42. Wijayaratne, A.L., and McDonnell, D.P. 2001. The human estrogen receptor-alpha is a ubiquitinated protein whose stability is affected differentially by agonists, antagonists, and selective estrogen receptor modulators. J. Biol. Chem. 276:35684-35692.

43. Fan, S., et al. 1999. BRCA1 inhibition of estrogen receptor signaling in transfected cells. Science. 284:1354-1356.

44. Saji, S., et al. 2001. MDM2 enhances the function of estrogen receptor alpha in human breast cancer cells. Biochem. Biophys. Res. Commun. 281:259-265.

45. Nawaz, Z., et al. 1999. The Angelman syncromeassociated protein, E6-AP, is a coactivator for the nuclear hormone receptor superfamily. Mol. Cell. Biol. 19:1182-1189.

46. Thomas, S.M., and Brugge, J.S. 1997. Cellular functions regulated by Src family kinases. Annu. Rev. Cell Dev. Biol. 13:513-609.

47. Rosen, N., et al. 1986. Analysis of pp60c-src protein kinase activity in human tumor cell lines and tissues. J. Biol. Chem. 261:13754-13759.

48. Tansey, W.P. 2001. Transcriptional activation: risky business. Genes Dev. 15:1045-1050.
49. Belsches-Jablonski, A.P., et al. 2001. Src family kinases and HER 2 interactions in human breast cancer cell growth and survival. Oncogene. 20:1465-1475.

50. Sheehan, K.M., et al. 2005. Use of reverse phase protein microarrays and reference standard development for molecular network analysis of metastatic ovarian carcinoma. Mol. Cell Proteomics. 4:346-355.

51. Iwao, K., et al. 2000. Quantitative analysis of estrogen receptor-alpha and -beta messenger RNA expression in breast carcinoma by real-time polymerase chain reaction. Cancer. 89:1732-1738.

52. Pegram, M.D., Pauletti, G., and Slamon, D.J. 1998. HER-2/neu as a predictive marker of response to breast cancer therapy. Breast Cancer Res. Treat. 52:65-77.

53. Nicholson, S., et al. 1990. Epidermal growth factor receptor (EGFR) as a marker for poor prognosis in node-negative breast cancer patients: neu and tamoxifen failure. J. Steroid Biochem. Mol. Biol. 37:811-814.

54. Oh, A.S., et al. 2001. Hyperactivation of MAPK induces loss of ERalpha expression in breast cancer cells. Mol. Endocrinol. 15:1344-1359.

55. Biscardi, J.S., et al. 1999. c-Src-mediated phosphorylation of the epidermal growth factor receptor on Tyr845 and Tyr 1101 is associated with modulation of receptor function. J. Biol. Chem. 274:8335-8343.

56. Arnold, S.F., Obourn, J.D., Jaffe, H., and Notides, A.C. 1995. Phosphorylation of the human estrogen receptor on tyrosine 537 in vivo and by Src family tyrosine kinases in vitro. Mol. Endocrinol. 9:24-33.

57. Arnold, S.F., Obourn, J.D., Yudt, M.R., Carter, T.H., and Notides, A.C. 1995. In vivo and in vitro phosphorylation of the human estrogen receptor. J. Steroid Biochem. Mol. Biol. 52:159-171.

58. Shah, Y.M., and Rowan, B.G. 2005. The Src kinase pathway promotes tamoxifen agonist action in Ishikawa endometrial cells through phosphorylation-dependent stabilization of estrogen receptor (alpha) promoter interaction and elevated steroid receptor coactivator 1 activity. Mol. Endocrinol. 19:732-748.

59. Sisci, D., et al. 2004. Fibronectin and type IV collagen activate ERalpha AF-1 by c-Src pathway: effect on breast cancer cell motility. Oncogene. 23:8920-8930.

60. Shao, W., Keeton, E.K., McDonnell, D.P., and Brown, M. 2004. Coactivator AIB1 links estrogen receptor transcriptional activity and stability. Proc. Natl. Acad. Sci. U. S. A. 101:11599-11604.

61. Guo, Z., et al. 2006. Regulation of androgen receptor activity by tyrosine phosphorylation. Cancer Cell. 10:309-319.

62. Salghetti, S.E., Caudy, A.A., Chenoweth, J.G., and Tansey, W.P. 2001. Regulation of transcriptional activation domain function by ubiquitin. Science. 293:1651-1653.

63. Fukuchi, M., et al. 2001. Ligand-dependent degradation of Smad3 by a ubiquitin ligase complex of ROC1 and associated proteins. Mol. Biol. Cell. 12:1431-1443.

64. Nawaz, Z., and O'Malley, B.W. 2004. Urban renewal in the nucleus: is protein turnover by proteasomes absolutely required for nuclear receptor-regulated transcription? Mol. Endocrinol. 18:493-499.

65. vom Baur, E., et al. 1996. Differential liganddependent interactions between the AF-2 activating domain of nuclear receptors and the putative transcriptional intermediary factors MSUG1 and TIF1. EMBO J. 15:110-124.

66. Alarid, E.T., Preisler-Mashek, M.T., and Solodin, N.M. 2003. Thyroid hormone is an inhibitor of estrogen-induced degradation of estrogen receptoralpha protein: estrogen-dependent proteolysis is not essential for receptor transactivation function in the pituitary. Endocrinology. 144:3469-3476.

67. Fan, M., Nakshatri, H., and Nephew, K.P. 2004. Inhibiting proteasomal proteolysis sustains estrogen receptor-alpha activation. Mol. Endocrinol. 
18:2603-2615.

68. Shang, Y., Hu, X., DiRenzo, J., Lazar, M.A., and Brown, M. 2000. Cofactor dynamics and sufficiency in estrogen receptor-regulated transcription. Cell. 103:843-852.

69. Hassapoglidou, S., Diamandis, E.P., and Sutherland, D.J.A. 1993. Quantification of $\mathrm{p} 53$ protein in tumor cell lines, breast tissue extracts and serum with time-resolved immunofluorometry. Oncogene. 8:1501-1509.

70. Cariou, S., et al. 2000. Down-regulation of p21WAF1/CIP1 or p27Kip1 abrogates antiestrogen-mediated cell cycle arrest in human breast cancer cells. Proc. Natl. Acad. Sci. U. S. A. 97:9042-9046.

71. Egan, C., et al. 1999. Activation of Src in human breast tumor cell lines: elevated levels of phospho- tyrosine phosphatase activity that preferentially recognizes the Src carboxy terminal negative regulatory tyrosine 530. Oncogene. 18:1227-1237.

72. Tibes, R., et al. 2006. Reverse phase protein array: validation of a novel proteomic technology and utility for analysis of primary leukemia specimens and hematopoietic stem cells. Mol. Cancer Ther. 5:2512-2521. 